\title{
THE IMMUNITIES OF THE STATE AND GOVERNMENT ECONOMIC ACTIVITIES*
}

\author{
Vernon G. SETSER $\dagger$
}

\section{INTRODUCTION}

It is the purpose of this discussion to present a general account of the developmental tendencies and present status of immunities of the state-that is, the exemption of the state, its government, or its instrumentalities from legal liabilities to which private persons or associations of such persons are subject-with special reference to the relationship of such immunities to the growing participation of the state in economic pursuits that in the great majority of communities are carried on principally by private persons. Although the subject is essentially a legal one, it has aspects of significance for the political scientist, for the economist, and for the intelligent citizen in any walk of life who is concerned with furthering equality of opportunity and with suppressing or modernizing obsolete doctrines or practices that hinder the development of society in accordance with its best ideals and principles. Despite the broad implications of the problem, however, any discussion must, perforce, rely almost entirely upon legal literature, for the subject has been little considered by other than the legal profession. The present article seeks to provide a reasonably accurate general picture, but without pretense at being a technical legal essay.

The immunities of the state that are of significance in the consideration of state trading and state economic activities generally may conveniently be dealt with under three headings: ( 1 ) immunity from taxation; (2) immunity from regulatory laws; and (3) immunity from jurisdiction of the courts. The third heading is probably the one that covers what are generally regarded as the most serious problems; at any rate, jurisdictional immunity has received by far the most attention. Immunity of state instrumentalities from taxation is recognized as creating troublesome conditions, particularly in the United States, where a conflict in state-federal relations is involved. With respect to the second category, about all that can be said is that such immunities are known to exist, that they could create problems of considerable magnitude, but that the subject has received little attention from any quarter.

Many lawyers and publicists of a liberal bent find most immunities intolerable because they violate the concept of legality and the ideal of justice. They are con-

- The views expressed in this paper are those of the writer only, and they should in no way be imputed to the United States Department of State.

+ A.B. I925, University of Montana; M.A. 1926, University of Illinois; Ph.D. I936, University of Pennsylvania. Foreign Relations Oficer, Bureau of Economic Affairs, United States Department of State. Author, The Commercial Reciprocity Policy of the United STates, I774-I829 (r937), and articles on historical and governmental subjects. 
cerned primarily with the fact that the escape of the state instrumentality from the normal jurisdiction of the courts results in a denial of justice for the person who has suffered from violation of contract or from tort at the hands of the immune entity. Granted that there now remain few classes of cases that cannot somehow and to some extent be prosecuted against the state, there is still concern that the manner in which immunities have been restricted leaves the probability of deficiencies in the application of justice-such as unjustifiable delays, procedures that are unfair or discriminatory against the private litigant, frustrating requirements of proceeding in an inconvenient forum, and procedural rules that weight the scales to the advantage of the state. Undoubtedly, considerations deriving from the ideal of justice, emphasizing that the principle of equality before the law requires that agencies of the state must not be above the law, have been most influential in bringing about, often by means of judgments of the courts, the extensive limitations that have been widely imposed upon the jurisdictional immunities of the state.

In the context of the problems resulting from the immense expansion of state economic enterprise, however, broader bases appear for objection to state immunities than the mere difficulty of individuals in obtaining justice. State enterprise versus private enterprise has become one of the major conflicts of our time. In those areas where the two must function side by side, the establishment and maintenance of competitive equality is a matter of some importance. Extension of jurisdictional immunity to a public enterprise may make it more difficult for the competing private enterprise to live. The enjoyment of tax immunity by a public enterprise not only subjects the taxpaying competitor to the risk of direct injury, but may tend to increase the tax burden upon all private enterprise. Exemption of state instrumentalities from general regulatory laws could also increase the load that private competition must carry.

The interests of the community affected by the activities of the public and private enterprise are also implicated, as is the welfare in certain respects of the state itself. The jurisdictional immunities of the government instrumentality may discourage private firms from doing business with it. It seems that doubt about the means for the settlement of disputes is one of the minor factors, for example, that militates against improvement in the commercial relations between the United States and the Soviet Union. The nonliability to taxes of government-controlled economic entities results in the constriction of the tax base available for the support of governmental and social services of affected communities. David E. Lilienthal, successful manager of the Tennessee Valley Authority, considered the subjection of the public enterprise to the jurisdiction of the courts in the normal way as highly desirable from the standpoint of the enterprise's own welfare and efficiency. "Further," he wrote, ${ }^{1}$ the ability of a Government enterprise to enter into firm commitments is dependent on the applicability to it of the ordinary legal procedures which private businesses follow in

${ }^{1}$ Lilienthal \& Marquis, The Conduct of Business Enterprises by the Federal Government, 54 Harv. L. REv. 545, 568 (194I). 
their contractual and other relations. ... Where the Government engages in business activity, the existence of those same relationships [ordinary legal relationships between litigants and between lawyer and client] is essential, since protection of private rights. requires amenability of the agency to suit, while the efficient conduct of its affairs similarly necessitates a correlative right on the part of the agency to sue and make settlements.

In case international intercourse should be prejudiced by the uncertainties, inequalities, and outright hindrances resulting from the special advantages derived by state enterprises from their immunities, the latter might be regarded as falling into the category of barriers to international trade, along with excessive tariffs, quantitative restrictions, cartels, etc.

What is the raison d'être of state immunities and the explanation of their survival into a period in which they run counter to important aspirations and objectives of society? Their origins have been traced to medieval concepts, although it appears. that even in the Middle Ages, with that period's primitive governmental institutions, they were not applied as completely or endorsed as fully as some advocates and judges: have apparently regarded as proper in more recent times. All societies, presumably, have considered the state and its government, possibly because government is regarded as the author of the laws and the source of justice, as not properly subject to the same liabilities, procedures, and penalties as private persons. Certainly, when governmental functions were limited largely to military affairs, police matters, administration of justice, maintenance of primitive communications, and providing the financial means for such operations, the small number of contacts between government and governed minimized the importance of the facile settlement of disputes: between the two. But in the Roman Empire, where governmental authority was: exalted to the highest degree, the state in its property relationships was suable in the courts. In most of the countries of Continental Europe, the influence of the Roman law, together with that of principles of early Germanic law stressing rights of theindividual against the governing authority and of similar principles derived from early modern concepts of natural law, have supported the maintenance of limitations upon claims of the sovereign to immunity and have facilitated marked progress toward an acceptable degree of equality in justice for state instrumentalities andi private enterprise.

In the countries that have inherited the English common law, however, immunities of the sovereign and attitudes toward them have developed in a different way. Borchard has written: ${ }^{2}$

Only in democratic England and republican America do we find the absolutist metaphysics: of divine right and sovereign immunity arrayed in the full regalia of their theological vestments, reincarnating for a twentieth century society the ancient credo of Bodin andl Hobbes.

He might well have included the members of the British Commonwealth in his: statement. But it should be recalled that since he wrote, the common-law countries:

' Borchard, Governmental Responsibility in Tort, 36 YALE L. J. I, 3 (1926). 
hàve made commendable progress in a liberal direction. It has been frequently said that the great respect for sovereign immunity in the common-law countries derives from the principle that "the King can do no wrong." At any rate, the rule developed in England that the King was not subject to the jurisdiction of the courts, except to the extent and in the manner to which he would consent; and the extent and the manner were severely circumscribed. This rule influenced the early decisions of the United States courts, since it was considered a principle of the common law. But later in this country, decisions supporting immunity from jurisdiction came to be justified on more rational grounds-namely, that protection of government and its officials from interference and annoyance through their being subjected to suit was necessary for the efficient carrying out of the transcendently important functions of government.

The immunities appertaining to foreign states have had a somewhat different origin and development, although the essential elements are related. They have been more generally recognized and respected than those of the territorial sovereign, and governments and courts have been more reluctant to come to grips with the need for limitation. They also seem to have originally been related to the prerogatives of the personal sovereign. In modern times, however, they have been justified mainly on the grounds that all states being equal and independent, submission of one state to the jurisdiction of another would be derogatory to the former's dignity and independence, and that foreign relations could not be properly conducted by the executive authorities if court jurisdiction were asserted.

Since there has been relatively little attention given to the subject of the immunities of state instrumentalities from tax liability and from regulatory legislation applicable to private enterprises, there is little information available as to the theories upon which their justification must rest. Doubtless, state instrumentalities engaging in economic activities have appeared to be analogous to such instrumentalities engaged in purely governmental activities, and the imposition of taxes or the enforcement of regulations designed to control private enterprises have been considered as unthinkable in the former case as in the latter. Moreover, it is difficult to avoid the conclusion that as a general rule, the policy of exemption from taxation is logically inherent in the original decision for the government to enter the activity. There is probably little justification from an economic standpoint, and less from the administrative, for an enterprise that depends upon the state for investment funds, and must either plow back its surplus earnings or cover them into the treasury, to segregate a portion of them for return in the form of tax payments. The only fundamental difficulty arises when there are autonomous tax jurisdictions, and the authorities in the lower echelons are precluded by state ownership from tapping the resources of the enterprise for the support of the public services for which they are responsible.

Once established, immunities of the state have tended to linger on for many reasons. Precedents and vested interests have been established that are difficult to change. What may well be referred to as the fiscal-mindedness of legislators and 
executive officials has been and still is a major defense of some aspects of state immunity. For example, the slowness of the states of the United States to make tort claims a subject for adjudication by the courts has been due to fear of the cost to the state of awards-a fear that the experience of those states with liberal tort-claims legislation seems to have proved unfounded.

\section{IMIMUNITY FROM TAXATION}

The situation with respect to the immunity of state instrumentalities from taxation varies greatly from country to country, and within countries, as concerns different classes of activities and types of taxes, without much indication of any clearly definable systems or logical rules. As to taxation applicable directly to instrumentalities of foreign states, there seems to be more of a common pattern; but even here, not all the signs point in the same direction. As in the case of immunity from jurisdiction, a substantial body of opinion is highly critical of tax immunities, particularly where it can be argued that they restrict the tax base substantially or where they extend to commercial activities in competition with private enterprise. ${ }^{3}$

In the United States, different principles apply as regards taxation of federal instrumentalities by the states and state instrumentalities by the federal government. The federal government, of course, seldom applies taxes to its own activities, however organized, although there is no question of its power to do so. In a line of decisions beginning with $M c$ Culloch v. Maryland in I8Ig, ${ }^{4}$ the federal courts, seeking to protect the national government against interference by the states, established firmly the rule that no state tax could be applied directly to a federal activity. They even went much further and expanded the doctrine to prohibit any state tax, whatever its incidence, that resulted in any significant economic burden upon the federal government. This meant, for example, that private contractors on government projects-indeed, any private concern or citizen performing services for the Government-could share the immunity. The effect of the rulings was so restrictive upon the taxing power of the states that strong pressure developed for a change. Within the past half century, the Supreme Court, in a new line of decisions, relaxed the doctrine protecting private interests, so that only state taxes whose legal incidence was upon the federal government were forbidden, unless greater immunities were authorized by statute; and a series of decisions handed down in $195^{8}$ has gone even farther in

'The Hoover Commission's hostility toward United States Government "business enterprises" was based in part upon their immunity from taxation. "The Government business-type enterprises, except in a few instances, pay no taxes, and pay little or no interest on the capital invested. . . . Moreover, in addition to the fact that most of them pay no taxes, they deprive the Government of taxes which would otherwise be paid by private enterprise if it conducted these operations. Therefore their claims of financial success are often wholly invalid; and, worse, with the advantages they receive from the Government, they are unfair competition." 4 U.S. Comm'N on Organization of the Executrve Branch of the GovernMent, Business ENTERPRises xii (I955).

i7 U.S. (4 Wheat.)* 316 (1819). 
limiting the immunity of private concerns engaged in government work. ${ }^{5}$ In certain circumstances, too, Congress has seen fit to mitigate the local effects of tax immunity by providing for payments in lieu of taxes, as, for example, in the case of the Tennessee Valley Authority.

On the side of the states, the instrumentalities of the state are normally immune from taxes of the state itself. There appears to be no constitutional rule preventing a state from taxing the instrumentality of another state if it should enter the jurisdiction, but no case of such taxation has come to the attention of the writer. The principal problem with regard to the immunity of state activities from taxation has arisen from relationships with the federal government. The federal courts have tended to protect the states on the same grounds-preventing interference of one sovereignty with another-that have provided the basis for exemption of federal activities from state taxes, but not to the same extent. The decisions have distinguished between the essential governmental activities of a state and its activities of a proprietary nature, or of a type normally carried on by private enterprise. ${ }^{7}$ Such state activities as the sale of alcoholic beverages and mineral water have, for example, been held subject to federal taxation. ${ }^{8}$ According to Ratchford, the Supreme Court, under prevailing doctrines, does not allow the following forms of taxation to either the federal government or the states:

(I) taxes directly upon an essential government activity; (2) property taxes upon property owned by governments or governmental agencies; (3) property taxes resting directly or indirectly upon government bonds; (4) excise taxes upon sales directly to governments or governmental agencies; (5) income taxes upon the interest on government bonds.

In Great Britain, as in the Commonwealth generally, the traditional principle that the Crown is not deemed to be bound by any statute, unless there is clear evidence that it was intended to be bound, has operated to exempt public instrumentalities from taxation. But in some of the legislation establishing the entities to operate the nationalized industries, it is specifically provided that they shall be liable for both general and local taxes. ${ }^{10}$

In Canada, federal instrumentalities are, by provision of the British North America Act, immune from provincial property taxes, and provincial instrumentalities

\footnotetext{
${ }^{\circledR}$ See Ratchford, Intergovernmental Tax Immunities in the United States, 6 NAT'亡 TAx J. 305 (1953); Powell, The Waning of Intergovernmental Tax Immunities, 58 HARv. L. Rev. 633 (x945), and The Remnant of Intergovernmental Tax Immunities, id. at 757. The recent decisions referred to are United States v. City of Detroit, 355 U.S. 466 (1958); United States v. Township of Muskegon, 355 U.S. 484 (1958); and City of Detroit v. Murray Corp. of America, 355 U.S. $4^{89}$ (1958).

54 STAт. 626 (I940), I6 U.S.C. \$83I(1) (1952).

' See Ratchford, supra note 5; Rice \& Estes, Sales and Use Taxes as Affected by Federal Governmental Immunity, 9 VAND. L. REV. 204 (1956).

${ }^{8}$ South Carolina v. United States, I99 U.S. 437 (1950); Ohio v. Helvering, 292 U.S. 360 (I934); New York v. United States, 326 U.S. 572 (I945).

${ }^{\circ}$ Ratchford, supra note 5, at 33I-32.

${ }^{20}$ See Wolfgang Friedmand, Law and Social Change in Contemporary Britain 63, 206.09 (ig51).
} 
from federal property taxes. ${ }^{11}$ The policy has been adopted, however, that Crown corporations, both federal and provincial, should make "fair and equitable" payments in lieu of taxes to municipalities. The Dominion Government has made its "proprietary corporations," such as Trans-Canada Airlines, liable for the federal income tax. There is no constitutional necessity, apparently, for the provinces to exempt their own instrumentalities from taxation. But the province of Saskatchewan, which has gone far in the socialization of economic activities, does not, for example, make its enterprises liable for municipal taxes, although grants in lieu of taxes are allowed. ${ }^{\mathbf{2}}$ Provincial corporations are not exempt from federal sales taxes, although departments of the provincial governments proper are immune.

The immunity status of government instrumentalities in Australia is particularly confusing, ${ }^{13}$ and the subject is of unusual interest because of the extent to which the state participates in economic activities. It appears to be the general policy to exempt government-controlled enterprises from taxation, the argument being that taxation would accomplish little, except complicate government bookkeeping. Theré is, however, no uniformity. The government-owned railway system, for example, is exempt from taxation, but the entity that operates Trans-Australian Airlines is not exempt. The different treatment is probably due to the fact that the railway system is a government monopoly, while Trans-Australian Airlines operates in competition with privately-owned lines. The Aluminium Industry Commission is exempt from state taxes but subject to national taxes other than the income tax. The Shipping Board is exempt from national taxes but subject to state taxes. In New Zealand, the degree of direct competition with private enterprise seems to furnish the criterion for the imposition of taxes. ${ }^{14}$ A few enterprises, such as the National Airways Corporation and the Bank of New Zealand, are fully liable. South African public enterprises are not usually subject to taxation, the view being taken, as in Australia, that assessment of taxes merely necessitates an additional bookkeeping operation. $^{15}$

Among many of the principal countries of the western part of Continental Europe, there appears to be more of a common pattern with respect to the tax treatment of government instrumentalities. ${ }^{16}$ In Italy, France, West Germany, and, to some extent apparently in Sweden, entities of the state engaged in economic activities are organized and treated in much the same way as private enterprises, and many of

\footnotetext{
${ }^{11}$ British North America Act of 1867,30 \& 31 VICT. c. 3. See Hodgetts, The Public Corporation in Canada, in Wolfgang Friedmann (Ed.), The Public Corporation 51, 67, 69-70 (1954).

${ }^{12}$ See Blakeney, Saskatchewan Crown Corporations, in id. at 91, 99.

${ }^{18}$ See Sawer, The Public Corporation in Australia, in id. at r, 33-36.

14 See Webb, The Public Corporation in New Zealand, in id. at 267, 295-96.

${ }^{15}$ See Price, The Public Corporation in South Africa, in id. at 302, 314.

${ }^{10}$ See Drago, The Public Corporation in France, in id. at 108, 126, 130; Friedmann \& Huffnagel, The Public Corporation in Germany, in id. at 138, 145; Muggia, The Public Corporation in Italy, in id. at 241, 257; Strömberg, The Public Corporation in Sweden, in id. at 324, 335. For an enlightening discussion of the problems of obtaining exemption of United States defense activities abroad, see Efron \& Hill, Foreign Taxes on United States Expenditures, 23 U. CiN. L. REv. 371 (1954).
} 
them are liable to taxation in like manner to private enterprises. Special exceptions exist, of course, where special tax treatment or full exemption is provided, usually in the legislation establishing the instrumentality, but the effort has been made, seemingly with some success, to assimilate many public enterprises to private enterprises in matters of taxation.

Of especial interest is the subject of tax immunity within the Soviet Union. ${ }^{17}$ Since, all economic activity of any consequence is state activity, the solution of the problem of providing income for local governmental administration was of major consequence. That solution was not dissimilar to the solution of the like problem in capitalist countries. Except in certain fields of activity judged to be of special economic or strategic importance, and, therefore, exempted from local taxes, such as railroads, civil aviation, and the mining of certain highly valued metals, the public corporations that operate the economy are taxed by the local soviets on the land and buildings used. In addition, the central government levies an income tax and a turnover tax upon the corporations. The latter is applied to products at time of manufacture, or, in the case of corporations in the service trades, to operations as measured by gross income. More than two-thirds of the budget of the central government is financed by this tax. The rate of income tax is ten per cent of net income, unless net income exceeds planned profits and construction requirements of the corporation, in which case, all surplus income is payable as an excess profits tax.

It appears to be the general practice of governments to accord immunity to instrumentalities of foreign states in the case of taxes the incidence of which would be directly upon such instrumentalities, although specific evidence of the tax status of state enterprises carrying on activities in countries other than the United States in competition with private enterprise is not readily available. There appears to be a definite tendency toward the development of a rule of international law supporting immunity for movable property owned by a foreign state, and possibly for real property, or at least for real property held for public use. ${ }^{18}$

In the United States, the income of foreign governments from any source within the country is exempted from the federal income tax. ${ }^{10}$ Such governments, their agencies, and officers have, in the past, also been exempted from certain federal excise taxes in the case of transactions paid for by the foreign government. ${ }^{20}$ There have been numerous inconsistencies in United States practice, however. In 1922, for example, a dispute arose over the taxation by the United States of a Maine corporation wholly owned by Nicaragua, whose corporate purpose was the operation of railways and steamship lines of Nicaragua. The initial United States position was that the corporation was a separate legal entity of American nationality and was not

\footnotetext{
${ }^{17}$ See Hazard, The Public Corporation in the U.S.S.R., in Wolfgnnc Friedmann (Ed.), The Pumlic Corporation 374, 394-95 (I954).

${ }^{18}$ See 2 Charles Cheney Hyde, International Law 847 (I945); Bishop, Immunity from Taxation of Foreign State Owned Property, 46 AM. J. INr'L L. 239, 240, 256 (I952).

${ }^{\text {IV }}$ INT. REV. CODE OF I954, $\$ 892$.

${ }^{20}$ See Fairman \& King, Taxation of Friendly Foreign Armed Forces, 38 AM. J. INr'L L. 258, 266 (I944); 4 Green H. Hackworth, Digest of International Law 775 (1942).
} 
entitled to immunity as a part of the government of a foreign state. After an interval of several years, however, the decision was taken to refund the taxes collected. ${ }^{2 x}$ In another case, occurring in 1933, however, the Treasury Department refused any concession. It involved a request that the Chinese Government Agency in New York, purchasing agent for the Government of China, be exempted from excise taxes affecting the official business of the Agency. In refusing the exemption, the Treasury Department contended that the Agency was not entitled to immunity under international law, and, while it might be proper government policy to accord exemption, that policy should be expressed by means of a treaty or statute. ${ }^{22}$

The opinions of state courts and officials have by no means given uniform support to the immunity of foreign states. Restrictive rulings have been made in certain cases, and in California, the attorneys general have sought to distinguish property for "public" use from other property of foreign states for application of the immunity rule. ${ }^{23}$ The principal American court decision on the subject was rendered by the Court of Appeals of Kentucky, in $1923 .{ }^{24}$ The suit concerned the attempt of county authorities to tax certain tobacco belonging to the French tobacco monopoly. The court related the matter of immunity from taxation to that of immunity from suit, pointing out that even if the tax were upheld as legal, payment could not be enforced, since the French Government was not suable. The effect of a decision against the French Government was also stressed. Said the court, "We know of nothing more calculated to degrade the dignity of an independent nation than for another to attempt to exercise over it the soverign right of taxation." 25 In a few court cases in other countries, immunity has been denied to property owned by foreign states, but the tendency seems to be to accord immunity as to property taxes. ${ }^{2 B}$

In a series of commercial treaties negotiated between 1948 and 1956,27 the United States included a provision containing a mutual waiver of immunity from taxation for publicly-owned or controlled enterprises of either treaty partner engaged in commercial, industrial, shipping, or other business activities within the territories of the other. The primary purpose of these treaty provisions was to provide an equitable rule to apply in the case of foreign state enterprises established in the United States pursuant to other provisions of the treaties. These clauses are not considered to be of such a nature as to impose taxes where the law exempts foreign government instrumentalities, but they would undoubtedly bar claims to immunity from a treaty state if imposition of taxes upon foreign state enterprises were provided by law.

${ }^{21}$ See 2 HACKwORTH, op. cit. supra note 20 , at $475-76$ (194I).

${ }^{22}$ See 2 id. at $482-83$ (I94I).

${ }^{28}$ See Bishop, supra note 18 , at 245-50.

${ }^{24}$ French Republic v. Board of Supervisors, 200 Ky. 18, 252 S.W. 124 (1923). See also Bishop, supro note $I 8$, at $240-41$.

${ }^{25}$ French Republic v. Board of Supervisors, $200 \mathrm{Ky} .18,22,252$ S.W. 124, I25 (1923).

${ }^{20}$ See Bishop, supra note I8, at 255 .

${ }^{27}$ See note 92 infra. 


\section{IMMUNITY FROM REgULATORY LAWS}

Immunity of governmental instrumentalities from regulations governing private persons and entities is derived in the common-law countries from the principle that statutory provisions that would have the effect of divesting pre-existing rights are not applicable to the state unless a clear legislative intent to subject it thereto is shown. In the United States, the courts have applied this rule to the advantage of the federal authorities $^{28}$ in a number of important cases. The United States has, for example, been held to be exempt from the requirements of the law prohibiting the issuance of injunctions in labor disputes, ${ }^{29}$ from provisions of the Bankruptcy Act, ${ }^{30}$ and, as landlord, from rent control regulations in the District of Columbia. ${ }^{31}$

Under the federal supremacy doctrine, the states are not permitted to apply regulations, under their police power, that would interfere with federal activities. It has been held, for example, that a contractor need not obtain a state license when constructing federal facilities within a state; ${ }^{32}$ that the United States may build a dam within a state without regard to a state law making all dam construction subject to approval by the state engineer; ${ }^{33}$ that a federal soldiers' home is exempt from state regulations regarding the serving of food; ${ }^{34}$ and that the Department of Agriculture may distribute fertilizer to farmers without complying with state inspection laws. ${ }^{35}$

In the United Kingdom, the immunity of the Crown from statutory regulations has been confirmed in a number of fairly recent court decisions, among them a case involving failure to comply with landlord and tenant (rent control) regulations. A case similar to the latter has also been reported from Australia. In India, a few years ago, a municipal enactment of Bombay authorizing the construction of drains through private and municipal property was considered not to oblige the Crown to comply with respect to its property. ${ }^{36}$

- The subject of the immunity of state instrumentalities from the applicability of general regulations in the countries of Continental Europe does not appear to have been specifically studied. Presumably, however, under the doctrine of the assimilation of public commercial corporations to the status of private corporations, the former would, in most cases, be subject to the regulations applicable to similar private entities.

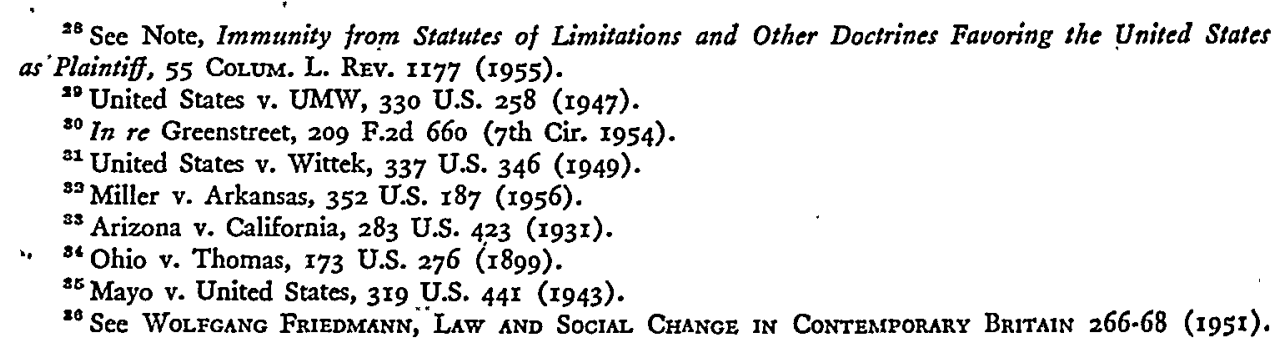


III

\section{IMMUNITY FROM JURISDICTION OF COURTS}

As concerns immunities from the jurisdiction of the courts, it is the immunity of the territorial sovereign within his own domain, not the immunity of foreign states, that possesses the greatest potential for adding to the problems arising from state activity in the economic sphere. State trading is obviously of greater impact on the domestic than on the international side. It is at home that the powers of the state are greatest, both with respect to protecting its own privileges and with respect to competition with private enterprise. International intercourse is much more vulnerable to injury from impediments established by the local sovereign to adjudication in his own courts of disputes arising, for example, from his own purchases of foreign products, sales of national products, and other transactions having effects beyond his own borders or upon aliens. One must make haste, however, to emphasize that those impediments are no longer of unlimited proportions, and that governments and tribunals almost everywhere have recognized the implications of the proliferations of state enterprise and acted, to a greater or less extent, to redress the balance.

The present situation of the United States Government with respect to immunity from suit is far removed from that once prevailing, when the private act of Congress or the frequently frustrating proceedings against an individual government officer who might be held personally liable was the only recourse of a claimant. Beginning with the Court of Claims Act of 1855 , which was greatly strengthened by legislation passed in 1863 and modified by the Tucker Act of 1887 (giving the federal district courts concurrent jurisdiction with the Court of Claims in cases involving sums of $\$ 10,000$ or less), ${ }^{37}$ and capped by the Federal Tort Claims Act of I $946,{ }^{38}$ a creditable body of legislation has been built up, establishing a system under which a very great proportion of disputes between the people and the Government can be adjudicated in a way quite comparable to that prevailing in the case of disputes between private persons. But the system is by no means perfect; there are too many limitations, exceptions, and uncertainties in the law. Contract claims amounting to more than $\$ 10,000$ can be prosecuted only in Washington, D. C., which may be an inconvenient forum for many in this large country. An alien may have access to the Court of Claims only upon proof that the country of which he is a national permits United States citizens to prosecute claims against its government in its courts. ${ }^{39}$ Although such a rule has nothing to do with justice, it is only moderately burdensome in most cases, since nearly all countries can doubtless make an acceptable showing of reciprocity. But the system for the prosecution of claims relating to contract and to property is generally regarded as good. ${ }^{40}$

${ }^{37} 24$ STAr. 505, 28 U.S.C. $\$ 1346$ (1952).

${ }^{38} 60$ STAT. 842 , as amended, 28 U.S.C. $\$ \$ 2671-80$ (1952).

${ }^{30} 62$ STAT. 976 (1948), 28 U.S.C. $\$ 2502$ (1952). See Developments in the Law-Remedies Against the United States and Its Officials, 70 HaRv. L. Rev. 829, 875-84 (1957), for a discussion of remedies under the Tucker Act.

${ }^{10}$ See Harry Street, Governmental Liabidity it-12 (1953). 
The Federal Tort Claims Act has, however, been described as "riddled with exceptions." manner, and to the same extent as a private individual under like circumstances" is, in fact, deceptive. ${ }^{2}$ Specific exceptions from the classes of torts for which claims may be prosecuted include, for example, losses or injuries resulting from negligence in the transmission of mail, from "discretionary" actions of officers, and from a long list of intentional torts, such as assault and battery, false imprisonment, and malicious prosecution. Although suits by aliens are not precluded by the Act, actions on claims arising in foreign countries are specifically excluded. Provision has been made by separate legislation, however, for administrative settlement of such claims within specified limitations as to amounts. ${ }^{43}$ Jury trial of claims against the United States is not permitted, which, in itself, constitutes a substantial protection for the state over many private defendants. Government corporations are much less likely to be accorded immunities by the courts than are other types of instrumentalities. ${ }^{44}$

There are also certain significant elements of traditional sovereign immunity that the federal government has not surrendered in the legislation and which the courts tend to protect, at least in part. ${ }^{45}$ The remedies that the legislation provides are limited substantially to monetary damages. The cases in which affirmative remedies -mandamus, injunctive relief, and specific performance-will be provided are few. Also, the Government may enjoy advantages in the nonapplication to it of certain procedural rules, such as discovery of documents. As plaintiff, it is exempt from statutes of limitations; and if it loses a suit, it normally does not have to pay costs (although successful tort claimants may be allowed costs other than attorney's fees). As to enforcement of judgments, sovereign immunity remains intact. Execution against public property is still unacceptable; the carrying on of the public business would be interfered with if such property were seized.

The states have, in general, made much less progress than the federal government in extending governmental liability for breach of contract and injuries to persons and property. More progress has been recorded with respect to contractual liabilities than

\footnotetext{
\$2 Henry M. Hart \& Herbert Wechsler, The Federal Courts and the Federal System II 43 (I953).

60 STAT. 842 (1946), 28 U.S.C. $\$ 2674$ (1952). See Developments in the Law-Remedies Against the United States and Its Officials, 70 HARv. L. Rev. 829, 889-92 (1957); Davis, Tort Liability of Governmental Units, 40 Mins. L. Rev. 751, 779-91 (1956); Note, Judicial Limitations under the Federal Tort Claims Act, 38 Minn. L. Rev. 634 (1954); Gellhorn \& Lauer, Federal Liability for Personal and Property Damage, 29 N.Y. U. L. REv. 1325 (I954); James, Tort Liability of Governmental Units and Their Officers, 22 U. CHI. L. REv. 6ro (1955).

ta 70A Stat. 154 (1956), ro U.S.C. \$2734 (Supp. V, 1958); 49 Stat. Ir38 (1936), as amended, 31 U.S.C. $\$ 224 \mathrm{a}$ (I952); 70 Stat. 890 (1956), 5 U.S.C. \$ rog (Supp. V, 1958). See also Davis, supra note 42, at 760-61; Gellhorn \& Lauer, supra note 42, at 1342-44.

"See Developments in the Law-Remedies Against the United States and Its Officials, 70 Harv. L. REv. 829, 840-48 (1957).

${ }^{45}$ See STreET, op. cit. supra note 40 , at $131-42$, 166-82; Note, Judicial Limitations under the Federal Tort Claims Act, 38 Mins. L. REv. 634 (1954); Developments in the Law-Remedies Against the United States and Its Officials, 7o Harv. L. REv. 829, 846-74, 923-35; Note, Immunities from Statutes of Limitations and other Doctrines Favoring the United States as Plaintiff, 55 Colum. L. REv. 1177 (I955).
} 
with respect to torts. ${ }^{48}$ Settlement of claims by private legislative act is still a common practice, with its uncertainties and likelihood of logrolling, favoritism, and graft. ${ }^{47}$ The methods for settlement of claims employed by the states fall generally into three classes: action in individual cases by the legislature; consideration by an administrative board, sometimes with settlement authority, sometimes with authority merely to report and recommend to the legislature; and adjudication by a court. ${ }^{48}$ The constitutions of several states forbid suits against the sovereign. New York has yielded much of its immunity, and its court of claims has wide jurisdiction in both contract and tort. Several other states have adopted fairly modern legislation in the subject matter. ${ }^{49}$

The evolution of law and practice with respect to state responsibility in the United Kingdom and the countries of the Commonwealth during the last century has been similar to that in the case of the federal government in the United States. ${ }^{50}$ To begin with, only the narrowly circumscribed path of proceeding by petition of right was available to those who thought they had a claim against the Crown. There was, of course, the possibility of actions against individual officers of the Government, which often offered little hope of satisfaction, and the possibility that a public corporation would be held not to possess the immunities of the Crown. The petition of right could be productive only in case the Attorney General, who possessed unlimited discretion in the matter, should grant a "fiat." Venue was highly restricted, being originally limited to the Court of Exchequer. Generally, only cases involving recovery of or compensation for property that had passed into the possession of the Crown and contract could be pursued through petition of right. Aside from certain very limited classes relating to property, the Crown was not actionable in tort. Procedures were somewhat simplified by the Petition of Right Act of $1860,{ }^{51}$ but the system was not substantially altered until I947. The Crown Proceedings Act of that year ${ }^{52}$ abolished the petition of right and made the Crown subject to private law liabilities, including liability in tort and suit in the ordinary courts, to a very great extent. These liabilities are limited in many respects in much the same way as in the case of the federal government in the United States, except that tort liability is subject to fewer specific exceptions in Great Britain. ${ }^{53}$ There are many uncertainties as to the application of the Act, due to lack of precision in the drafting and because there has not yet been time for the courts to interpret it for many

\footnotetext{
${ }^{10}$ Among the more recent surveys of immunity practice among the states are Davis, supra note 42 ; Note, Administration of Claims Agdinst the Sovereign, $68 \mathrm{HARv}$. L. REv. 506 (1955); Note, Sovereign Immunity of the States, 40 MinN. L. REv. 234 (1956); Leflar \& Kantrowitz, Tort Liability of the States, 29 N.Y. U. L. REv. I363 (1954); James, supra note 42.

${ }^{17}$ See Note, Administration of Claims Against the Sovereign, $68 \mathrm{HARv}$. L. Rev. 506, 509 (I955).

${ }^{18}$ See $i d$. at 507 .

${ }^{10}$ See id. at 507-I7; Lellar \& Kantrowitz, supra note 46, at 1407 .

. ${ }^{\circ 0}$ See Laski, Responsibility of the State in England, 32 HArv. L. Rev. 447 (19I9); STREET, op. cit. supra note 40, at I-6; Wade, Liability in Tort of the Central Government of the United Kingdom, 29. N.Y.U.L. REV. 1416 (1954).

${ }_{31} 6 \& 37$ VICT. c. 69 (N.I.). $\quad$ s2. ro \& II. GeO: 6, c. 44.

${ }^{23}$ See Street, op. cit. supra note 40, cc. $5,6,7$.
} 
situations. The great commercial corporations that operate the industries nationalized since the World War II are not governed by the Crown Proceedings Act, but are liable to civil action in the same way as private corporations. ${ }^{54}$

Canada established a special federal court, the Exchequer Court, in 1887 to hear cases against the Dominion. Proceeding was by petition of right upon "fiat" of the Governor General, approved by the Minister of Justice. Jurisdiction extended to both contract and tort. The legislation has been progressively liberalized, and a number of important steps have been taken within the last decade.55 In 1950, corporate Crown agencies were made subject to the jurisdiction of the provincial courts. In 1953, torts resulting from negligence and not involving claims of more than $\$$ rooo were also submitted to the jurisdiction of county or district courts. Australia preceded the United Kingdom by many years in completing its liberalization of the law regarding state liabilities. ${ }^{58}$ The Judiciary Act of $1903^{67}$ made it possible to sue the Commonwealth in both contract and tort without petition of right. A somewhat controversial question at present in the Commonwealth is the extent to which the numerous public corporations in the country stand under "the shield of the Crown," entitling them to the enjoyment of whatever is left of the state immunities. This is a problem that is encountered also, to some degree, in Canada and the United Kingdom. Like some of the states of the United States, and, apparently, some of the Canadian provinces, a few of the Australian states have lagged far behind the central government in surrendering their immunities. New Zealand and the Union of South Africa seem to have reached a stage of advancement approximately equivalent to that of Australia. ${ }^{58}$

The greatest innovations in the recognition of governmental responsibility have been produced by French judicial proficiency and resourcefulness. The individuality of the French system results from two developments: first, the establishment and growth of a system of administrative courts, separate from the ordinary civil courts and manned by judges with administrative experience, having jurisdiction over most types of cases involving the state; and, secondly, the formulation and application of new legal principles in the settlement of such cases. The system of administrative courts grew out of the decision taken during the Revolution that the operations of the state should be freed from interference by the regular courts and that the new system of law should be developed from the creative judgments of the Council of State, at the head of the administrative hierarchy in individual cases.

Special rules in the law governing government contracts have been developed by the French courts, generally giving emphasis to the paramount importance of

ss See Wade, supra note 50, at $\mathrm{r}_{429-30}$.

${ }^{50}$ See Hodgetts, supra note II, at 65-70; French, Rights in Contract and Tort in Relation to the Crown, Chitry's L. J. 76-77 (1956).

${ }^{50}$ See Street, op. cit. supta note 40, at 6; Sawer, supra note 13, at 36-42. Sec also Wolfgano Friedmann, Law and Soctal Change in Contemporary Britain 206 et seq. (195i).

st An Act to Make Provision for the Exercise of the Judicial Power of the Commonwealth, II Commonwealth Acts, 1903-34, p. 1379, Aug. 25, 1903 (Australia).

${ }^{58}$ See Street, op. cit. supra note 40 , at 7; Price, supra note 15 , at 312-14. 
the proper carrying on of the public services, but, nevertheless, taking care to provide adequate protection of the private contractor. ${ }^{59}$ But it is in the field of tort claims that the French have gone farthest in assuring protection for the private person. ${ }^{60}$ The basic doctrine has been that liability rests upon fault-either the fault of the state administrative service, in which case the state is liable for damages to be determined in the administrative courts, or the personal fault of the state employee, in which case the latter is suable in the civil courts. But in distinguishing the two classes of fault, very difficult in almost any circumstances, the decisions have tended to widen the former category and narrow the latter. As a final development, the jurists of the Council of State have begun to abandon more and more the concept of fault and to hold the state liable for damages on the basis of the doctrine of risk-that is, that "the very function of the service creates a risk which must be borne by the public equally." eyes might appear to be somewhat bizarre. For example, a restaurant proprietor was awarded damages because his business suffered on account of the blocking of a highway during public improvement work; and a claimant was indemnified when the executive authorities refused, for overriding policy reasons, to evict trespassers from the claimant's property pursuant to a court order. ${ }^{62}$ It seems evident that France has not only come closest to the ideal of placing the state upon a plane of equality with the private person as concerns legal responsibility, but has sometimes gone further and made the state liable in cases where the private person possibly would not be. Although in France, as in most other countries, the property of the state is normally immune from execution, there seem to be certain situations in which it is possible to enforce an unsatisfied judgment against public property. ${ }^{63}$

The cases over which the administrative courts have jurisdiction are public law cases. Some important matters involving the state are private law matters, within the jurisdiction of the civil courts and subject to the civil code. Among these are certain types of contracts, particularly contracts not closely related to the performance of a public service. A commercial lease would be an example. ${ }^{64}$ Of more importance from the viewpoint of those concerned with the problems of state trading is the subjection to the civil courts of a large group of state instrumentalities that perform functions comparable to those performed by private persons. A number of these industrial and commercial corporations, such as that for the operation of the Alsace potash mines, were established after World War I. Included in the group, also, are the great public enterprises that were nationalized after 1945, such as the electricity and gas industries. In nearly all respects, the legal status of these instru-

\footnotetext{
${ }^{20}$ See STREeT, op. cit. supra note 40 , at IOO-OI.

${ }^{\circ} \mathrm{See}$ id. at 56-80; Jacoby, Federal Tort Claims Act and French Law of Governmental Liability: $A$ Comparative Study, 7 VANd. L. Rev. 246 (1954); Schwartz, Public Tort Liability in France, 29 N.Y. U.L. REv. 1432 (I954).

${ }^{01}$ Street, op. cit. supra note 40 , at 67.

${ }^{02}$ See id. at 67-68. See also Bernard Schwartz, French Administrative Law and the Comaron LAW WORLD 288-302 (I954).

${ }^{10}$ See id. at $182-83$. "ot See id. at 83 .
} 
mentalities, except with respect to execution against their property, has been assimilated to that of private concerns. ${ }^{65}$

In the other countries of West Europe, what may be described as a relatively advanced stage of recognition of the responsibility of the state has been achieved, although the situation varies from country to country, and none appears yet to have approximated, in a comprehensive range, the degree of liberalization developed in France. ${ }^{68}$ Liability for contract seems universally accepted. In other fields, a distinction is generally made between acts of authority-that is, essential acts of government-for which no liability is assumed, and acts of management, over which civil courts exercise jurisdiction. Thus, in Belgium, the state could not be sued for damage caused by a military vehicle engaged in normal military activities, but it could be sued if the damage occurred while the vehicle was being used in distributing food to the civilian population, the former being an act of authority, the latter not. For the most part, liability for tort in all countries is based upon fault. West Germany seems to have taken a long stride toward accepting liability for acts of public authority, and Italy makes no distinction between the two categories of acts. Certain classes of state instrumentalities in West Germany are regarded as public-law entities and actionable only before the administrative courts; included in this group are the railway system and certain municipal utilities. On the other hand, a number of state. economic entities, including other gas and electricity utilities and certain mining enterprises, are private-law entities and within the jurisdiction of the civil courts. The Italian state is normally actionable in the civil courts, although suability in the administrative courts may be provided for in certain circumstances; and this applies generally to the numerous public economic entities which are said to account for about half of all productive enterprise in Italy.

In Latin America, the law of state liability has developed along lines similar to the law of Continental European countries. Generally, the law regards the state as a corporate entity and subject to the jurisdiction of the civil courts in much the same way, as any other juristic person. As in Continental Europe, distinction is made between acts of authority and acts of management. In Argentina, the development of liability doctrine has differed from that in other countries, the rationale being comparable to that in the common-law countries that suit must depend upon consent. But a law of Igoo provides that civil action may be initiated without prior legislative consent. ${ }^{.7}$

$\therefore$ It has been said that "unlike other legal systems, the Soviet legal system does not know the notion of immunity of the domestic government, and its instrumentalities

$\because$ Sc: Drago, supra note I6, at Ii8-ig, 126-35.

"ós Sée STREET, op. cit. suprä note 40, at 19-24; Friedmann \& Huffnagel, supra note 16, at 144-45, 150-52; Muggia, supra note 16 , at 243, 244-47, 262-64; Braband, Liability in Tort of the Government and Its Employees: A Comparative Analysis with Emphasis on German Law, 33 N.Y.U.L. REv. 18 (1958). wier'See Irizarry y Puente, The'Responsibility of the State as a "furistic Person" in Latin America, I8 Tur. L. REv. 408, 42I-22 (r944). 
from the jurisdiction of its own courts." ${ }^{88}$ It appears, however, that the preferred procedure for complaints against government bureaus for allegedly illegal acts is through administrative channels. ${ }^{69}$ The complainant may address himself directly to the head of the office responsible for the act; or he may proceed through the Office of the Prokuror, a sort of public prosecutor, through a State Control Office, or through Communist Party channels. An elaborate procedure exists for the investigation and disposition of cases, with the possibility of appeal to the higher administrative officers. The surveillance of administrative acts to assure their legality and to protect the citizen against bureaucratic encroachment upon his rights is a particular responsibility of the Prokuror's office. The economic instrumentalities of the state, the public corporations, are, however, subject to suit with little restriction. ${ }^{70}$ An individual complainant may take his case to the ordinary courts. In a case involving two public corporations, however, the proper state arbitration tribunal has jurisdiction. Soviet law permits foreign corporations that have been licensed to do business in the country to have access to the courts upon the same terms as Soviet citizens. Foreign corporations that are not licensed are permitted to sue in Soviet courts defendants who are resident within Soviet territory, provided the country of which the plaintiff is a national accords reciprocity. ${ }^{71}$ In practice, however, disputes between foreign corporations and Soviet entities are more usually settled by arbitration, as provided by contract or by international agreement. ${ }^{72}$

\section{IV}

\section{Qualified IMMUNITY}

By the early nineteenth century, the principle had become well established that the foreign state, when its interest became involved beyond its boundaries, was immune, unless it chose to waive its immunity, from the jurisdiction of the courts of the territorial sovereign, except with respect to matters concerning real property within the territories of the latter, other than property for diplomatic establishments, and with respect to succession. That principle was widely regarded as a rule of international law. Within the last century, however, there has been recorded very considerable progress away from that simple formula-progress that a stark realist, focusing on world-wide conditions, might feel inclined to describe as largely in the direction of chaos.

In the last quarter of last century, the courts of certain civil-law countries, led by those of Belgium and Italy, began to break away from the doctrine of absolute immunity. Following the principles of their domestic law, the judges and the doctrinal writers postulated a duality within the state which enabled them to undertake

\footnotetext{
${ }^{\text {os }}$ Pisar, Soviet Conflict of Laws in International Commercial Transactions, 70 HARv. L. REv. 593, 649 (1957).

${ }^{\circ 0}$ See Nove, Some Aspects of Soviet Constitutional Theory, I2 Modern L. Rev. I2, 34-36 (I949).

${ }^{70}$ See Hazard, supra note $\mathrm{x} 7$, at $39 \mathrm{x}-93$.

${ }^{71}$ See Pisar, supra note 68, at 605-06.

${ }^{72}$ See id. at 606-I3.
} 
to distinguish between the foreign sovereign's acts of public authority or sovereign functions, and his acts of a private character. With respect to the former, he retained his immunity; with respect to the latter, he was held to be properly subject to suit before the local courts in the same way as a private citizen. The acceptance of this theory was hastened and widened by developments of the last forty years: the monopolization of industry by, and the extension of the state-trading activities of, the Soviet state; the nationalization of substantial segments of industry in other countries; and the growing consciousness throughout the world of the need for more careful regard for and extension of "the rule of law." Decisions have been rendered in accordance with the restrictive theory in many Continental European countries, in Egypt, and in several countries in Latin America. The United Kingdom and the other members of the British Commonwealth, the United States, the Soviet Union, and the satellite countries are usually classified as supporters of absolute immunity, ${ }^{78}$ although the United States Department of State has recently veered from that doctrine, and strong criticism of it is being heard in Great Britain. In consequence of these developments, it would appear that it can no longer be maintained that there is any requirement of international law that a foreign state be exempted from court jurisdiction. ${ }^{74}$

The immunity of the property of the foreign state from execution is regarded as a separate matter from that of immunity of the state instrumentality from suit; and the immunity principle as concerns the former has, to date, enjoyed the greater degree of respect. Even in the countries where the doctrine of limited immunity prevails as to suit, the foreign sovereign's property is more usually held secure from attachment or sequestration. Two explanations may be given as to why this is so: since the territorial sovereign, under the most liberal responsibility laws, remains exempt from execution, the foreign sovereign should not be less favored; and interference with the foreign sovereign's property is likely to entail a threat to peaceful international relations. But there are indications that this part of the absolute immunity doctrine, too, is beginning to weaken. There have been a number of cases in the countries adhering to the restrictive theory where the courts have shown a disposition to order execution upon state property, although, as yet, a clear-cut rule has not been established. ${ }^{75}$ Liberally inclined doctrinal writers have not hesitated

\footnotetext{
7s The assignment of countries to the absolute or restrictive theory groups may depend upon the particular court decisions the assigner considers determinative. In a number of countries, the situation is unclear. The latest extensive survey appears to be that by Lauterpacht, The Problem of Iurisdictional Immunities of Foreign States, 28 BRIT. YB. INT'L L. 220, 250-92 (195I). See also the State Department letter to Department of Justice, the so-called Tate Letter, 26 Dep't Stare Burz. 984 (1952), and the statement of George S. Leonard, Department of Justice, minimizing the extent of acceptance of the restrictive theory, The United States As Litigant in Foreign Courts, in AM. Soc'y INT'L L. Proc. 95 (1958).

${ }^{24}$ See Fitzmaurice, State Immunity from Proceedings in Foreign Courts, 14 BRIT. Y日. INr'L L. 99, II7-1 8 (1933); Lauterpacht, supra note 73, at 226-32; Lalive, L'immunité de jurisdiction des Etats et des Organisations internationales, in 3 Hague Academy of International LAw, Recueil Des Cours 205, 25I-52 (1953).

${ }^{75}$ See Lalive, supra note 74, at 275-78; Lauterpacht, supra note 73, at 241-43.
} 
to advocate restriction upon the privileges of the state as to execution upon its property. ${ }^{70}$

Although the doctrine based upon a distinction between the public and the private acts of the state has provided the means for an extensive breach in the bulwarks of sovereign immunity, the doctrine itself contains recognized weaknesses that have retarded its spread and are likely to prevent its universal adoption as immunity law. It assumes that the traditional functions of the state are the essentially sovereign ones, and that the newly assumed economic functions, having been taken over from the private sector, may, because of their nature, be properly assigned a different and inferior status. It neglects to recall that state monopoly of the essentially sovereign functions has not at all times and in all places been complete, and that state activities in military affairs, justice, and even public finance, for example, sometimes came to be acts of public authority in a manner not wholly lacking in similarity to that in which the state has become involved in state trading and other economic activities. In practice, the problem in applying the restrictive theory arises from the lack of satisfactory criteria for determining which acts are public acts and which are private acts. ${ }^{77}$ Justice Van Devanter struck to the heart of the logical difficulty when he said in the Pesaro decision, "We know of no international usage which regards the maintenance and advancement of the economic welfare of a people in time of peace as any less a public purpose than the maintenance and training of a naval force."78 Consequent upon this lack of criteria, the decisions of the tribunals have been conflicting not only among the different countries, but also, on occasion, within the several national jurisdictions. ${ }^{79}$

The apparent impossibility of formulating objective criteria for differentiating between acts of sovereignty and private acts has induced many proposals looking to the formulation of a doctrine that would provide a more positive and reliable formula for limiting the immunity of the state. ${ }^{80}$ One approach that has received favorable attention would make the basis for according or denying immunity a determination of whether a private person could perform the act in question. A notable presentation of this approach is to be found in the "Draft Convention on Competence of

${ }^{70}$ Sec Lauterpacht, supra note 73, at 241-43; Lalive, supra note 74, at 279-80; Harvard Research in International Law, Draft Convention on Competence of Conrts in Regard to Foreign States, 26 Ax. J. INT't L. 455,706 et seq. (Supp. 1932).

${ }^{77}$ Professor Friedmann, however, sees no greater difficulty for the courts in establishing acceptable criteria in this matter than, for example, in determining what is "reasonable," as they so often have to do in the common-law countries. Friedmann, Some Impacts of Social Organization on International Law, 50 AM. J. INT'L L. 475,48 I (I956).

${ }^{78}$ Berizzi Bros. Co. v. S.S. Pesaro, 271 U.S. 562,574 (1926).

${ }^{70}$ See Lauterpacht, supra note 73 , at $222-24$, for an account of the conflicting judgments.

${ }^{80}$ The three proposals discussed here by no means exhaust the subject. Sce, e.g., Hervey, The Immunity of Foreign States When Engaged in Commercial Enterprises: A Proposed Solution, $27 \mathrm{MicH}$. L. Rev. 75I (1929), advocating a United States Act of Congress establishing jurisdiction over foreign state enterprises; Paul Shepard, Sovereignty and State-Owned Commercial Entities 98-1oo (I95I), in which the author argues that the state's engaging in commercial activities through a state-owned commercial entity should be construed as a waiver, ipso facto, of immunity; and Lalive, supra note 74, at 242, $257-72,287-89$, in which various reform proposals are reviewed, including suggestions for international conventions. 
Courts in Regard to Foreign States" of the Harvard Research in International Law. ${ }^{81}$ This project, formulated in 1932, would subject a foreign state to the jurisdiction of the local courts, except with respect to matters in relation to its public debt, if it should engage in an industrial, commercial, financial, or other enterprise within their jurisdiction that a private person could there engage in, or if it should perform an act within their jurisdiction in connection with such an enterprise, regardless of where established. This formulation has been criticized on the ground that it is sometimes very difficult to determine whether a specific class of act can be performed by a private person. ${ }^{82}$ Should the purchase of a warship, for example, by a foreign state be equated with the purchase of a yacht by a private person; or should the former be regarded as an act of sovereignty entailing exemption from suit? A curious result of the practical application of the Harvard Research formula would be that instrumentalities of a predominantly private-enterprise state would be entitled to a large measure of immunity within a socialistic state, while the latter's enterprises in the former's territories would be suable like private persons.

Professor Lauterpacht has come forward with a logical and practical proposal for solution of the problem, one that should be especially attractive to those familiar with the development of domestic immunity law and procedures within the United States and the British Commonwealth. ${ }^{83}$ Having satisfied himself that neither the absolute theory nor the restrictive theory of immunity has any foundation in international law, he concludes that a reasonable method of making the instrumentalities of the foreign state amenable to justice would be to assimilate the foreign sovereign as completely as practicable to the position of the territorial sovereign. Under such a plan, a British state instrumentality in the United States would be suable with respect to contract in the Court of Claims and in the federal district courts with respect to tort. It would be entitled to the same procedural privileges and exemptions that the law provides for the United States. Lauterpacht stipulates that there should be specified exceptions from the rule of assimilation, for which immunity should be retained: legislative acts of the foreign state; administrative and executive acts performed on its own territory; questions involving contracts that under the rules of private international law would not be within the competence of the courts concerned; questions concerning diplomatic privileges and immunities; and questions involving the seizure of a war vessel or military aircraft or the responsibility of the foreign state's armed forces.

A Swiss publicist, Jean-Flavien Lalive, in a study published in r953, submitted a plan also designed to minimize uncertainties and to limit immunity to a few essential categories of state activities. ${ }^{84}$ Lalive, like Lauterpacht, affirms the nonexistence of any requirement in international law for according immunity to foreign states. He has much respect, however, for the progress made by means of the doctrine distinguishing between acts of authority and private acts, and he sees a need

\footnotetext{
${ }^{81} 26$ AM. J. INr'L L. 455, 597 (Supp. 1932).

${ }^{83}$ Lauterpacht, supra note 73 , at 236-41.

${ }^{82}$ Lalive, supra note 74, at 259-60.

ss Lalive, stipra note 74 , at $285-86$.
} 
for building upon the accomplishments under that doctrine without revolutionary change. His objective is to provide authoritative guidance for the courts, so as to eliminate ambiguous or deficient judgments and to assure an appropriate degree of uniformity internationally in the application of the law. He would first restate the principle so as to emphasize general absence of a right to immunity: "The foreign state enjoys jurisdictional immunity only for certain acts of public authority." $\mathrm{He}$ would have this restatement accompanied by a limitative list of categories of acts of public authority for which immunity should be accorded, and the courts might add to or subtract from the list as experience might indicate the desirability. His list includes: internal administrative acts of the foreign state (e.g., expulsion of an alien); legislative acts (e.g., a nationalization law); acts concerning the armed forces; acts relating to diplomatic activities; and questions concerning public loans contracted abroad by the foreign state. It is Lalive's intent that in cases not covered by the list of exceptions, the state should be subject to local jurisdiction in the same way as private persons; he does not take into consideration, as Lauterpacht does, the intermediate stage represented by the "consent" legislation of the United States and the countries of the British Commonwealth.

The proponents of the reform projects described above vary somewhat as to the methods recommended for making their schemes effective. The Harvard Research project is in the form of a draft international multilateral convention. Lauterpacht suggests that his scheme of assimilation could be carried out by unilateral legislation or by international agreement, but his greatest hopes apparently lie in the direction of reform through the codification efforts of the International Law Commission of the United Nations. ${ }^{85}$ Lalive fears that an attempt at a multilateral convention would be frustrating, because of the tendency to achieve only a least-commondenominator level. He thinks that legislative or executive regulation on a unilateral basis would contribute to progress, though perhaps in a fragmentary manner, and that bilateral treaties would provide a very efficacious method. He concludes that the most desirable results, however, could be obtained through the establishment of a system of international courts, with jurisdiction over cases involving the liability of foreign states. ${ }^{86}$

Space and the plan of this discussion preclude any attempt to survey developments in this field on a country-by-country basis, but reference to and comment upon recent developments in the United States appear apposite. This country's historic adherence to the rule of absolute immunity, pursuant to Marshall's decision in The Schooner Exchange v. McFaddon ${ }^{87}$ has been mitigated by recourse to certain important exceptions that may, on occasion, result in bringing foreign state-trading enterprises to respond in justice. The most important of these applies to corporate entities owned or controlled by a foreign state. Relying upon another of Marshall's

\footnotetext{
${ }^{85}$ Lauterpacht, supra note 73, at 247-50.

${ }^{80}$ Lalive, supra note 74 , at $287-90$.

${ }^{87}$ II U.S. (7 Cranch)* 116 (1812).
} 
opinions, Bank of the United States v. Planters Bank, ${ }^{88}$ the courts have tended to deny immunity to such corporations, except in certain cases where they have chosen to conclude that the entity was, in fact, an arm of the foreign government. Another basis for exception from immunity has been a finding that a merchant vessel, for example, though owned by a foreign government, was not in possession of that government at the time of the cause of action. ${ }^{89}$

Following World War I, after which some of the war-spawned state entities continued to engage in economic activities in competition with private enterprise, and the state-trading programs of the Soviet Union became a cause of concern, a steady succession of professional writings appeared in periodical and book form criticizing the principle of absolute immunity and recommending reform. No American defenses of the old order of any consequence have appeared in print. ${ }^{.0}$ Prior to 1926 , the Department of State, in a number of instances, took the position that foreign states should not be entitled to immunity for their commercial activities.11 In that year, however, in the Pesaro case, the Supreme Court disregarded the views of the Department and accorded immunity to a merchant vessel owned and operated by the Italian Government. Thereafter, the Department abandoned its efforts to limit the immunity of foreign states and did not resume them until after World War II.

The group of United States commercial treaties containing an immunity waiver has previously been referred to. ${ }^{92}$ This waiver provision was not designed, however, to establish a general policy with respect to immunities of foreign states for the United States. The policy it represents was initiated in 1949, at a time when treaties were contemplated with a number of countries that were in the process of nationalizing large segments of their industries. The basic purpose of the treaties was to facilitate the admission of United States private enterprises into foreign countries in connection with programs for their economic development; but, of necessity, equal rights were stipulated for foreign enterprises to establish themselves in the United States. It was anticipated that the nationalization of enterprises that had branches or subsidiaries in this country and the expected efforts of certain state-owned industries to seek to set up establishments here would give rise to problems of adjustment to the American private-enterprise system. Hence, the inclusion of clauses to assure that such state-owned enterprises as might be entitled to treaty rights would not

${ }^{88} 22$ U.S. ( 9 Wheat.)* $904,907-08$ ( 1824 ). This case, of course, did not involve a foreign state, but one of the states of the United States. (1950).

${ }^{\circ}$ See Fensterwald, Sovereign Immunity and Soviet State Trading, 63 HaRv. L. Rev. 6r4, 6r9-20

${ }^{00}$ For a list of the principal authors and their writings, see Bishop, New United States Policy Limiting Sovereign Immunity, 47 AM. J. INT'L L. 93, 96 n. I3 (1953).

${ }^{91} 2$ HACKWORTH, op. cit. supra note 20 , at $429,437,438-4 \mathrm{r}$.

${ }^{02}$ See text at note 27 supra. A total of fourteen treaties containing the waiver were negotiated, of which those with the following countries have entered into force: Italy, Ireland, Greece, Israel, Japan, Federal Republic of Germany, Iran, Nicaragua, the Netherlands, and Korea. A typical waiver provision appears in Treaty of Friendship, Commerce, and Navigation With the Federal Republic of Germany, Oct. 29, 1954, art. XVIII, para. 2, [1956] 7 U.S.T. \& O.I.A. I839, T.I.A.S. No. 3593 (effective July 14, 1956). 
evade the liabilities to which private enterprises in competition with them were subject.

The waiver extends not only to immunity from suit, but also to immunity from execution of judgment, from taxation, and from any other liability to which private enterprise is subject. The waiver provisions were drafted in language which, when considered in the context of other establishment provisions, limits the effect to the sort of establishment situations here referred to. Although the waiver is expressed in reciprocal terms, it could have a bearing upon United States rights to immunity abroad only if this country should undertake to establish public enterprises, such as factories, department stores, or insurance companies, in countries with which the treaties are in effect. The limited restrictive policy of the treaties is comparable to that enforced administratively by the Civil Aeronautics Board when it makes a waiver of immunity a requirement for the issuance of a permit to a foreign air carrier. ${ }^{93}$

The most noted event in regard to the subject of sovereign immunity that has occurred within recent years was the public announcement in 1952 by the Department of State that thenceforward, with respect to its own action regarding requests from foreign governments for a grant of immunity from suit, it would follow the restrictive theory. ${ }^{94}$ The action referred to is the furnishing to the court, usually upon request of the foreign government concerned, of the Department's "suggestion and certificate" favoring the granting of immunity in the specific case, or the refusal to recommend immunity. This procedure has developed from the long-standing tendency of the courts to assign great weight to the views of the executive branch in a matter considered to be of importance in the conduct of foreign relations. In fact, in decisions handed down in the I940's, the Supreme Court seemed to take the position that the determination by the Department of State is binding upon the courts. ${ }^{95}$

In its announcement, the Department endorsed in a forthright manner the Continental European concept of the responsibility of the state under which "the immunity of the sovereign is recognized with regard to sovereign or public acts (jure imperii) of a state, but not with respect to private acts (jure gestionis)," disregarding the serious criticism a number of leading commentators have directed at that concept. $^{06}$ The policy set forth-and, indeed, prior United States practice in the premises-placed the responsibility upon the Department for determining whether a given act of the foreign state were of the essence of sovereignty, or a mere private act, a

${ }^{03}$ The authority for this is 52 STAT. 99I (1938), as amended, 49 U.S.C. $\$ 482$ (1952).

o' The announcement is in the form of a letter from the Department's Acting Legal Adviser, Jack B. Tate, to the Acting Attorney General, Philip B. Perlman, dated May 19, 1952. 26 Dep'T State BuLl. 984 (1952). The background and implications as envisaged at the time are authoritatively presented in Bishop, New United States Policy Limiting Sovereign Immunity, 47 AM. J. INT'L L. 93 (I953).

${ }^{05}$ Ex Parte Republic of Peru, 3 I8 U.S. 578, 587-89 (1943); Republic of Mexico v. Hoffman, 324 U.S. 30, 35-36 (1945). See also Lyons, The Conclusiveness of the "Suggestion" and Certificate of the American State Department, 24 BRIT. Yв. INT'L L. II6 (1947).

${ }^{00}$ See text at notes $80-86$ supra. 
responsibility widely held to be properly a judicial function. ${ }^{97} \mathrm{~A}$ reason given for the change in policy was that "the Department feels that the widespread and increasing practice on the part of governments of engaging in commercial activities makes necessary a practice which will enable persons doing business with them to have their rights determined in the courts." The announcement was generally received as a highly desirable progressive step, definitely aligning the United States with the practitioners of the restrictive theory. ${ }^{88}$

What the ultimate effect of the 1952 declaration will be upon United States policy in actual practice remains to be seen. Since its issuance, no really significant case has arisen to test the determination of the Government to be guided by the principles set forth, to indicate the criteria by which a determination is to be made as to what classes of acts are entitled to immunity, and to establish the firm precedent needed to fix the lines of a permanent policy. In the meantime, moreover, the kinds of perplexities and conflicting points of view that have always vexed reform attempts in the field of state immunities have begun to crop up. Any significant change in the policy applicable in the case of foreign state instrumentalities in the United States may be expected to have the potential, at least, of influencing the treatment of activities of the United States in foreign jurisdictions; and, at the present time, there is a vast preponderance of American governmental activities abroad that could perhaps be brought under the jurisdiction of foreign courts, over foreign state activities within the possible jurisdiction of the United States. Officials of the Department of Justice, charged with the onerous responsibility of defending the United States against claims arising abroad, prefer the effective and inexpensive defense of meeting nearly every proceeding with the plea that it is an unconsented suit against a sovereign. Weighty practical difficulties would be encountered, of course, in submitting United States governmental instrumentalities generally to the jurisdiction of foreign courts, one of the most embarrassing of which is lack of appropriations to cover payment of costs and judgments against the United States, unless Congress should decide to make provision therefor.

The Department of Justice position leans very heavily, therefore, to the side of the theory of absolute immunity for the foreign state. ${ }^{89}$ Faced with the pronounced general sentiment of the leaders of the legal profession in favor of the "rule of

${ }^{97}$ For critical comments upon the tendency of the executive branch to assume judicial functions in this subject matter, see Jessup, Has the Supreme Court Abdicated One of Its Functions? 40 AM. J. INr'L L. 168 (1946); Note, Judicial Deference to the State Department on International Legal Issues, 97 U. PA. L. REv. 79 (1948); Cardozo, Sovereign Immunity: The Plaintiff Deserves a Day in Court, 67 Harv. L. Rev. 608 (1954).

${ }^{88}$ Bishop, New United States Policy Limiting Sovereign Immunity, 47 AM. J. INT'L L. 93 (1953); Lalive, supra note 74, at 234-35; Cardozo, supra note 97; Brandon, Sovereign Immunity of Governmentowned Corporations and Ships, 30 ConNeLL L.Q. 42, 442-45 (1954); Reeves, Leviathan BoundSovereign Immunity in a Modern World, 43 VA. L. REv. 529, 554 (1957).

89 The Department of Justice position is most fully set forth by George S. Leonard, of that Department's Civil Division, supra note 73. The resurgence of absolute immunity doctrine within the Government is also indicated by developments in connection with the consideration of a proposed resolution on sovereign immunity at the 1958 Conference of the International Bar Association. A draft resolution borrowing much from the highly respected Harvard Research Draft Convention had been prepared by a committee, see Reeves, Good Fences and Good Neighbors: Restraints on Immunity of Sovereigns, 44 
law," to which both the present attorney general and his predecessor have lent public support, its officials have, however, proposed an approach of a sort to a limitation of foreign state immunities. They suggest an arrangement by treaty under which, on a reciprocal basis, the liabilities that each nation has assumed under its own law would be enforceable against it by foreign courts. ${ }^{100}$ Under such arrangement, for example, French courts would apply the Tucker Act, Federal Tort Claims Act, and other American legislation against the United States, while United States federal and state courts would apply French administrative law in suits against France. Apparently, the principal merit claimed for this proposal is that it would not increase the liabilities of any state above those it had accepted domestically, but would provide a litigant with a forum within his own country. Also, it would have the effect of keeping each country's liabilities uniform throughout the world, rather than allowing them to vary according to each country's laws. It would appear to be open to criticism, however, as a proposal for the extraterritorial extension of national laws, and would doubtless give rise to various sorts of procedural problems, as well as the usual difficulties accompanying attempts to interpret and enforce foreign law.

\section{Conclusion}

Although advocates of the limitation of state immunities have indicated concern lest these special privileges in the hands of instrumentalities engaged in economic activities endanger private enterprise and hinder the development of trade, the published materials available do not provide a factual basis for a conclusion that immunities per se constitute at the present time any grave or imminent danger. This is not to say, of course, that immunities are not deserving of special attention with a view to proper reform, or that the critical commentators have not helped to prevent them from becoming a more serious problem.

For a meaningful evaluation of the immunities of the state, as concerns their actual and potential effect upon economic affairs, studies quite different from any so far published are needed. Court decisions and records constitute a valuable source of information, but analysis needs to go farther than that of the legal investigator concerned principally with what the law is or ought to be. They need to be studied for the light they may throw upon the nature, seriousness, and dimensions of the problems arising from state immunities. Consultation with officials of private concerns as to their experience with immunities and some investigation in private business records might also be revealing. Analysis of actual business relationships between typical state instrumentalities and private enterprises should indicate the extent that immunity problems are of significance in such relationships. The ad-

\footnotetext{
A.B.A.J. 522 (1958), and was scheduled for adoption by the Conference. Because of the intervention of several high ranking federal officials, who took the position that such resolutions might make it more difficult for the United States to maintain its immunity from suit in foreign courts, American representatives at the Conference opposed the resolution and succeeded in having it deferred for further study and possible revision. See Anderson, The International Bar Association Conference at Cologne, Germany, 5 FED. B. NEWS 312 (1958).

${ }^{100}$ See Leonard, supra note 73, at I03; Brownell, Lawyers and a Government of Law, I3 RECORD of N.Y.C.B.A. 188,201 (1958).
} 
ministrative and legislative settlement of claims and the utilization of commercial arbitration procedures in settlements would have to be studied as essential parts of the picture. Even on the purely legal side, there are wide gaps in the accounts regarding jurisdictional immunities in many countries and generally with respect to exemptions from taxation and statutory regulation. Extensive research of such difficulty on this subject will probably not be considered justified, but until more realistic data are available, judgments on the economic implications of state immunities can represent little more than speculation.

On the basis of his exhaustive study of governmental tort liability in the United States, Professor Davis concluded that "of all deserving tort claims against federal, state and local governmental units, probably far more are paid today than are unpaid. ..."101 Probably one can do little better by way of describing the world-wide situation with respect to claims in general against governments than to adapt that statement accordingly. Defeats of justice unquestionably occur in business dealings between private and public enterprises, and state immunities are sometimes to blame. But defeats of justice also occur in business relations between private persons, and free access to courts is not always a complete solution. It seems a fair presumption that the business morality of governmental units averages higher than that in the private sector, and such a probability in itself might be thought to justify a special legal status for state instrumentalities. In any case, there appears to be no lack of a readiness on the part of private enterprise generally to deal with governments, and there are sometimes observable indications of a preference for dealing with them. Other deficiencies in the administration of justice, including such shortcomings as lack of trained judges, crowded dockets, unreasonable delays, and dishonesty of officials, are, on a world-wide basis, probably a far more serious handicap to free economic enterprise than results from state immunities. There is another side to the coin also. If state liabilities should be expanded indefinitely along such lines as indicated by certain decisions in France, ${ }^{102}$ for example, the monetary cost to private enterprise, by way of taxation, might be far more serious than the injuries resulting from the remaining vestiges of sovereign immunity. On the international side, especially troublesome problems may arise from claims of immunity for the state trading agencies of the Soviet Union and the satellites. Four decades of experience seem to have demonstrated, however, that state immunities do not constitute one of the major difficulties in the way of East-West trade, and that other problems solved, bargaining at the government level can produce a reasonable degree of protection for the private interests involved.

\footnotetext{
${ }^{101}$ Davis, supra note 42 , at 751 .

${ }^{102}$ In the Fleurette case, adjudicated by the Council of State in 1938 , damages were awarded against the state when a manufacturer of cream substitutes was forced out of business by legislation, cnacted at the behest of the dairy industry, forbidding manufacture and sale of such substitutes. La Flcurette, Conseil d'État, Jan. 14, I938, [1938] Recueil des arrets du Conseil d'Etat 25, [1938] S. III.25 (Fr.). In a similar case, decided in 1944, a sugar manufacturer was indemnified for loss resulting from a law, enacted to favor cereal producers, reducing the amount of sugar that might be used in brewing beer. See Davis, supra note 42, at 792-93; Jacoby, supra note 60, at 258.
} 